\title{
Aesthetic Adaptation as a Culture Strategy in Preserving the Local Creative Potentials
}

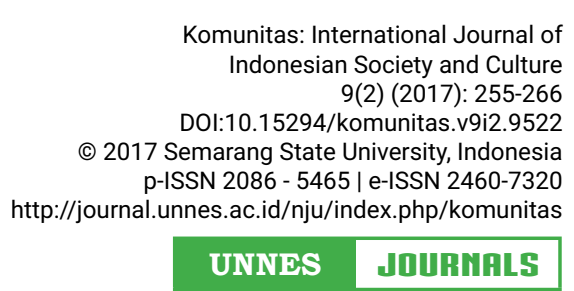

UNNES

\author{
Triyanto ${ }^{1}$, Mujiyono $^{2}$, Eko Sugiarto ${ }^{3}$ \\ Department of Fine Arts, Languange and Literature Faculty, Universitas Negeri Semarang, Indonesia
}

Received: March 2016; Accepted: August 2016; Published: September 2017

\begin{abstract}
This study aims to understand and explain the problems of aesthetic adaptation through the development of ceramic art design in Mayong Lor Village as a cultural strategy in facing market competition to maintain the local characteristics. The research data was through by participant observation technique, in-depth interview, and document data tracking. The results show the following: First, the type of ceramic products can be classified into four categories, namely: 1) celengan (piggy banks), (2) children s toys/remitance (keg, jars, cups, glasses, plates, paso, teapots, earrings, angklo, kekep) , (3) glassware for household purposes, such as jugs, kendil, padasan, and cowek, (4) decorative items (vases, jars, pots, wuwungan tiles, pencil pot, souvenirs, and carving. Aesthetically, the expression on ceramic pottery of Mayong Lor Village is simple and non-complicated as well as prioritizes the aspect of physical function which is oriented to economic value. Second, the social and cultural environment of Mayong Lor society creates typical patterns of interaction and lifestyle (with the support of its natural resources) resulting in the process of skill transfer of ceramic pottery traditionally from generation to generation and produces a unique and simple ceramic product. Third, in the midst of the strong influence of modern industrial pressures, the craftsmen struggle in the process of creativity by performing an aesthetic adaptation to develop new design with new artistic and economical values as the embodiment of a cultural strategy to maintain the creative potential of their local arts.
\end{abstract}

\section{Keywords}

aesthetic adaptation; culture; traditional ceramics; local art; preservation

\section{INTRODUCTION}

As a part of traditional art, ceramics as glassware of burned clay (Astuti 1994; Adhytman 1987; Yumarta 1982), in the making process, reflects the noble values of its society (Wolff 1989; Geertz 1973; Otten 1971). Therefore, in its glory era, the existence of traditional ceramic art shows its function (Sayogya 1985) which is able to improve social-cultural relations especially as a medium of socializa- tion, communication, and symbolization in various cultural events of society. Even, its physically manifested presence in aesthetic and unique aesthetic art products (Kisawa 2012) can be one of the capitals and symbols of the cultural identity of its maker commu-

\footnotetext{
Corresponding author

Jl. Raya Sekaran Gunungpati 50229 Semarang, Indonesia

Email

triyanto@mail.unnes.ac.id
} 
nity (Kayam 1981; Bourdieau 1986; Dillistone 2002; Sugiharto 2013; Carbon 2010, 2011).

However, in the present reality, the ceramic condition has largely experienced dysfunctional situation in its socio-cultural context. It is characterized by many facts that show the traditional culture of royalty in various regions experiencing the declining, stagnation, and even extinction. As a result, many industrial centers of ceramic pottery experience bankruptcy. Sidharta (1991) notes that in the 196os, ceramic art in Indonesia in his journey had died because the function, design, and quality of traditional pottery ceramics were considered to be no longer suitable for consumers. This empirical fact was strengthened by research results of Iswidayati (2009) which shows that the glory of ceramic centers in Indonesia was around 1960-1998.

After 2ooos until now, the life of the percussion in Indonesia begins to decline. This is because ceramic products made with traditional form designs and techniques are unable to compete with similar products in markets made of plastic or by modern industries (Chambers 1988). Under these conditions, the situation became more severe after a rise in fuel prices. Many home industries of ceramics went bankrupt and most of the craftsmen switched to another profession, migrated or became other workers in various factories (Suara Merdeka 2014). This, at least, indicates that working as ceramic craftsmen is economically incapable of being used as a guarantee of the family's source of income to meet the necessary living needs. Therefore, it is natural that such endeavors by the various creator communities are abandoned into historical memories of his past.

Meanwhile, Mayong Lor Village as one of the villages in Mayong District, Jepara Regency has historically been known as the center of the traditional ceramic art industry or the art of pottery. Until now, Mayong Lor's ceramics production still continues with all its dynamics. The business potential of Mayong Lor village community in ceramic pottery industry activity has become the identity and pride of Mayong Lor villa- gers. In addition, the potential of ceramic business has become the economic source of the village and its citizens from generation to generation (Mahbub 2010; Kathadinata 2005). The data from the Jepara Industry Office indicates that the existence of this ceramic industry has contributed economically (mayong.jeparakab.go.id/index.php/web/ data/6.8). As a result of the expression of popular art, Mayong Lor ceramic art has its own characteristics both from the aspects of materials, technical production, or form design, namely simple and non-complicated concepts (Sachari 1989; Karthadinata 2005).

In this context, pottery in Mayong Lor Village is unique as compared to other pottery industry conditions (Guntur 2005; Adimihardja 1986). First, when ceramic industrial centers in other regions have dimmed, Mayong Lor's ceramics industry can still survive. In fact, its existence has become a pottery center of Jepara regency. It is estimated that the strategy is by modifying the shape and design of pottery to suit the market demands. The adaptation is more oriented to the processing of more aesthetic forms. Although most wearable items are still produced, most craftsmen have begun to produce ornamental objects or even stand-alone artworks and souvenirs.

Secondly, the ceramics pottery industry in Mayong Lor has historically, until now, been going on for generations over six centuries and counting. Traditional regeneration processes often give rise to craftsmen's attitude when they encounter rapid changes or developments in the environment with the presence of faster and efficient technology making them less likely to use them directly (Koentjaraningrat 1986). In fact, the opposite situation happens. They prefer traditional ways that they consider more effective in delivering quality ceramics. In addition, craftsmen on the one hand still uphold popular values and still bring the spirit of locality as cultural expression (Chamim 2003). However, on the other hand, they often meet or cannot be separated from outside influences in the form of modernity that relies more on the culture of capitalism by eliminating the values of col- 
lectivity and the demand for novelty. In that aspect, it is estimated that adaptation strategies to maintain the pottery design will be able to adjust the market dynamics within the framework of the local identity that they have. This becomes an increasingly complicated and interesting issue because of its strong adaptability and existence is carried out by mostly poorly educated craftsmen. In addition, other facts indicate that the offer to switch professions outside the craftsman profession is sometime very tempting.

Thirdly, the things that influence the efforts of the formation of the design also appear to be an interesting issue because after all, the developing process of design is as a form of adaptation which cannot be separated from various internal and external factors (Bennet 1976; Moran 1979; Ellen 1982; Faerber \& Carbon 2012). Internal factor is more on the willingness of the craftsmen themselves to renew their work. External factors have a role in the development (innovation) of ceramic design. The factors often involve many supporting agencies either contributing directly or indirectly in giving its influence. The roles of influential local figures, successful craftsmen, and village government apparatus as well as related offices are supportive networks that contribute considerable influence (Rogers and Shoemaker 1973; Weber \& Khademian 2008; Raymond et al. 2010; Armitage et al. 2011).

Based on these facts, the adaptation strategy of new ceramic design in Mayong Lor Village as a traditional village in the era of modernity is interesting to study. This study also becomes very important because by understanding the pottery as a cultural artifact, the expression of noble values of its supporting community will be investigated (Sudiyati 2012). The existence of a ceramic as a product also cannot be separated from craftsmen, buyers, community culture, social environment, culture and related institutions which become parts of the framework of a holistic understanding. It is confirmed by Gopnic (2000) that ceramics can be used as a marker of some of the activities, habits, and behavior of the community, including those used to explain the arts, beliefs, trade, population distribution, and community intelligence (Babcoc 1989; Sudiyati 2012).

Based on various backgrounds of ceramic uniqueness in Mayong Lor Village Jepara, this research focuses on study of design development of ceramic art form of Mayong Lor Village in encountering of market competition in cultural perspective. The development of the design of ceramic forms is interpreted as a cultural strategy in the defense of the creative potential of local art in facing the outside cultural changes which are quite strong (Sedyawati 1991; Rohidi 2001; Runco 2007). The study is expected to provide a comprehensive understanding of the adaptation efforts of a local pottery design which are able to offer values in accordance with the development of the times.

The study and documentation on the various arts of pottery that have been produced by craftsmen Mayong Lor Jepara Village is expected to be able to assemble the structure of the formation or identity of the Mayong pottery. Therefore, it can be a strategy to survive by not leaving the uniqueness of its local characteristics. Through the knowledge and understanding of traditional art culture that has been obtained, the pride in the values of locality can be increased. Therefore, the efforts to develop the design of Mayong Lor ceramics both textually and contextually will be done by art supporters who have clear and measurable guidelines to run dynamically. This study aims are to understand and to explain the aesthetic adaptation mainly through the development of ceramic art form designs of Mayong Lor Village in facing market competition to maintain the characteristics of the locality.

The study employed a qualitative ethnographic approach (Spradley 1997). The subjects of the study were the community of craftsmen and ceramics sellers, as well as some community leaders in Mayong Lor Village. The study focused on: (1) the embodiment of ceramic form and expression of Mayong Lor Village of Jepara Regency in facing the market competition, (2) the 
social and cultural environment influences toward creation process done by craftsmen which enable the expression of locality value in ceramic products of Mayong Lor Village, Jepara Regency, (3) the aesthetic adaptation pattern in the development of ceramic shape design with the character of locality as a cultural strategy done by ceramic craftsman of Mayong Lor Village so that the creative potency of local art could survive in facing the market competition. The location of the study was in Mayong Lor Village. Data collection techniques used in this study were observations, in-depth interviews and documentation. The operationalization of the use of this technique was flexible in accordance with the conditions developed in the field with the main instrument of data collector of the human instrument (Rohidi 2011) i.e. the research team and the supporting team. In general, the data collected was then analyzed using a qualitative analysis approach. The analytical procedure was conducted through the process of reduction, presentation, and verification of data (Miles and Huberman 1992).

\section{Mayong Lor Village: General Overview} Mayong Lor village which is one part of Mayong District Jepara Regency, Central Java province of the north, is located about $24 \mathrm{Km}$ from the central regency government and $68 \mathrm{Km}$ from the provincial capital. The village has an area of $289,8 \mathrm{Ha}$. The village is bordered by some villages: Mayong Kidul and Blimbing Rejo Villages in the south, Pelem Kerep, Singorojo and Pringtulis Villages in the north, Tiga Juru, Kuanyar and Sengon Bugel villages in the west and Pring Tulis Village in the east. The total area of the village is divided into 4 hamlets, namely: Gleget, Krajan, Karang Panggung and Bendowangen Hamlets. Krajan and Bendowangen hamlets are the center of the ceramics industry, both tile and pottery.

When viewed from the position and its location not far from the district capital and regency capital, Mayong Lor Village is likely a village town. This is supported by the presence of a sizable village market and shops, as well as large school buildings and mosques on the side of a big road that is quite crowded with the hustle and bustle of traders' lives and public transport traffic, elementary school life, the life of Santri, the life of Madrasah or junior high school students and the daily life of the craftsmen both in the process of production and in the process of distribution of products. This condition has provided opportunities for the economic development of citizens, especially in the handicraft industry sector people who process raw materials of clay into bricks, tile, and pottery. In terms of basic livelihoods, the majority of the population works in the field of ceramic handicrafts, both tile ceramic and pottery ceramic. The other villagers work in various other occupational sectors.

\section{The Embodiment of Ceramic Form and Expression in Facing Market Com- petition}

Clay is a raw material used in making pottery ceramics. The raw material, for the ceramic craftsmen Mayong Lor, was originally obtained from within the village environment itself. Today, the hunt of clay for ceramic raw material is then moved to neighboring villages such as Pring Tulis, Pelem Kerep, and Tiga Juru Villages. Even since the eighties, this clay hunt has begun to shift outside the village neighbors some distance away to the Papringan-Tunggul area which is bordering area of Kudus Regency. Now, the main area that becomes the supplier of raw material source of clay is located in Gemiring Lor Village, Nalumsari District; a district in Jepara District that borders or becomes a neighbor of Mayong District. The tools used are pegot (rotary table), citakan, butsir, sisir, plat seng, skrup jeruji sepeda, mentur, benang atau kawat kecil, ember, bak penampung, cangkul, kain lap, pahat ukir, pisau, amplas, molen, kuas, ayakan (irig), rak, and furnace.

This final processing is ready to be used and formed into ceramics. This is a traditional way. Nowadays, the way of processing can be done by using a new tool in the form of molen machine that works to process the clay through the process of ground grinding machine. Clay that has been processed, if it will be made into ceramics, can be formed 
by using several techniques depending on the type of products to be produced. There are several kinds of shaping techniques, namely rotational, print, massage, print and plintir techniques. The rotary technique is commonly used by pottery ceramic artisans in Mayong Lor Village.

The process of forming ceramics with this rotational technique requires high concentration. However, because the craftsmen are generally accustomed and skilled, it looks very easy. For craftsmen, the first clay that is ready to be used is placed right on the center axis of the bot. Then, the soil is pressed firmly to stick and not shift for further rotation while the thumb is pressed right in the axis or the middle of the clay to form more holes which are less than $1 \mathrm{~cm}$ from the base. While continuing to rotate the table with their feet, the clay held is gradually pulled up slowly following the direction of hand movements to form a desired product. To smooth the process of creation, craftsmen usually wet their hands with water that has been provided. In this formation process, the function of the mentul tool is necessary in helping to form the body of ceramics.

The forming process is completed by smoothing the lips (edge) part of the products with a dampened cloth or sponge and the bottom part attached to the bucket is cut with wire or yarn. The products are then removed to dry in the shade. If the ceramics will be given additional decoration, then before drying process or in a semi-dry (Javanese: malem), it can be done by scratching, carving, sticking, stamping or punching the ceramic body according to the motif or decorative pattern that has been prepared before. In addition, there are times when, in a semi-dry state, ceramics are beautified by craftsmen by giving the coating of engobe (a coloring materials from red ground pulp) on the entire surface of the pottery by brushing it until it is evenly distributed. The next pro-

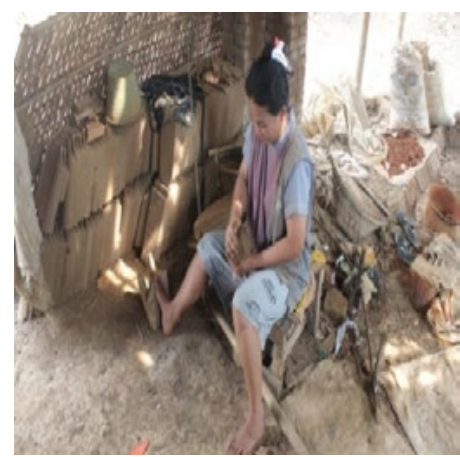

a

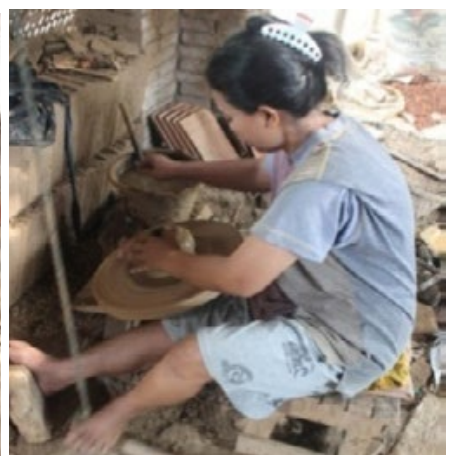

b

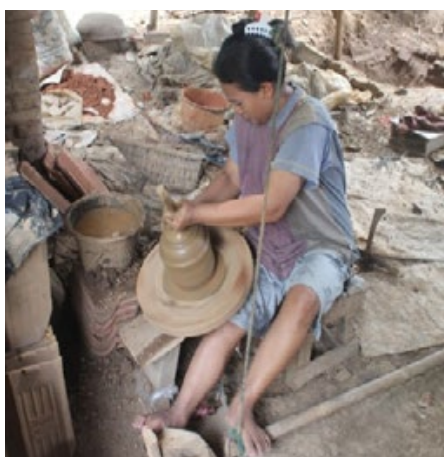

Figure 1. The Making Process of Ceramic using Rotational Techniques (mbubut) Typical from Mayong Lor Village

(Source: Author Documentation)

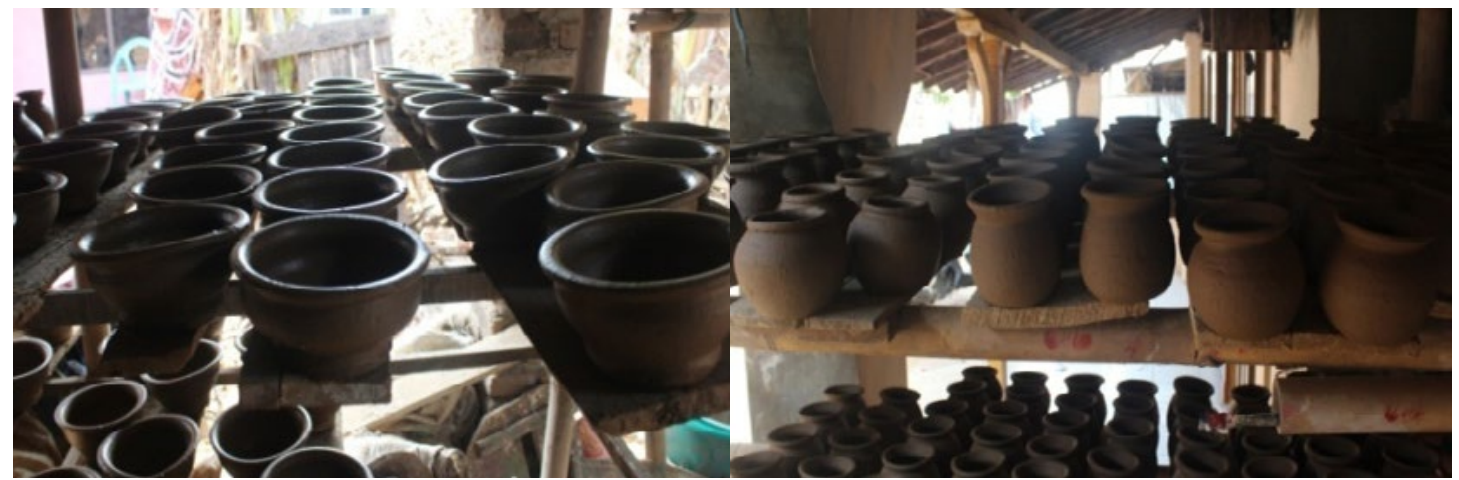

Figure 2. The Natural Dying Process By allowing the wind to dye it in the terrace (Source: Author Documentation) 
cess after formation is drying, burning, and finishing the ceramics. In the picture 1 and 2 can be seen the process of making ceramics and the results.

The type of products that are produced can be classified into four categories, namely: (1) celengan (piggy banks), (2) children>s toys/remitan (keg, jars, cups, glasses, plates, paso, teapots, earrings, angklo, kekep), (3) glassware for household purposes, such as jugs, kendil, padasan, and cowek, (4) decorative items (vases, jars, pots, wuwungan tiles, pencil pot, souvenirs, and carving. The sources idea of making these items mostly come from the legacy forms of hereditary tradition to meet the needs of kitchen equipment. Kendi, kendil, padasan, keg, cowek, children's toys or remitan (except piggy banks) are examples of goods which are made based on the existing form of kitchen appliances from the traditional heritage. Another source of idea of making the design of the form of ceramic products comes from the creation of the crafters through selflearning process or learning through training- The trainings are provided by various parties.

Most types of specific forms, such as piggy banks, remitan, jugs, kendil, padasan, and cowek are in a form of tradition which has existed for over generations. Among the various forms of this tradition, some have experienced the development of the design into a new form, for example the piggy bank creates its own variants. The rest of the various other forms are more because of the result of the design development which is either done by the craftsmen themselves by the process of self-study or by learning from the design of others or trainings. The variety of forms development includes jars, vases, pots, pot base, wuwungan tile, carving and souvenirs.

The diversity of these forms still reveals their aesthetic aspects. More specifically, the following exposes the aesthetic characteristics of the embodiments of the ceramic pottery forms mentioned above. A typical characteristic of such esthetic expression can be put forward as follows. Firstly, as a work of traditional art, the producti- on of Mayong Lor ceramics are local artistic expressions which are characterized by the use of raw materials and supporting materials derived from locally natural resources. Secondly, the production technology of making the products in general is still using traditional equipment. The main equipment is perbot (special rotation tool that is manufactured with a turntable in a tilted position that is driven with the left foot). Thirdly, the source of the idea of creation of the manufacture of ceramic products is generally derived from the hereditary heritage of generations, namely the need to meet household appliances, especially kitchen appliances. Fourth, from the embodiment of the form of ceramics products generally shows the aesthetic expression within simplicity which still reveals a unique, funny, and innocent impression.

Aesthetically, the simplicity of expression is seen in their forms (subject matter) which are not complicated and prioritize more on the aspects of physical function- economic value oriented. If there is an effort to give additional coloring, it is done spontaneously with brush strokes of primary color of paint cans or paint silk which is relatively cheap. Similarly, if there is an effort to provide ornaments, it is also done spontaneously by scratching the form using simple lines.

\section{The Influence of the Social and Cul- tural Environment on the Ceramic Creation Process}

From several craftsmen who are interviewed, it is obtained an explanation that they receive the skills to make pottery is indeed through the hereditary heritage of their respective predecessors. Surely, they cannot mention the number of years since when Mayong Lor ceramic pottery is starting to exist. The craftsmen can only say that the art of ceramics in their village have long been there and it is a legacy of their great grandfathers. The meaning of great grandfather refers to the heir lines above their own grandfathers and the punjer (heir-line point) is undetectable anymore. However, from the written document of the early Mayong Lor 
Embodiments and Types of Ceramics produced in Mayong Lor Village

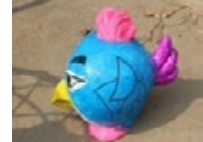

Celengan (Piggy Bank)

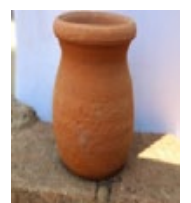

Remitan

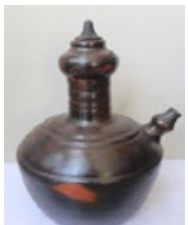

Kendi (Jug)

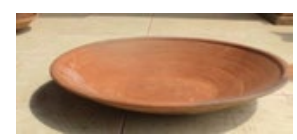

Cowek

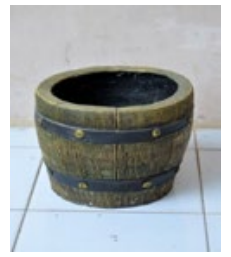

Pot

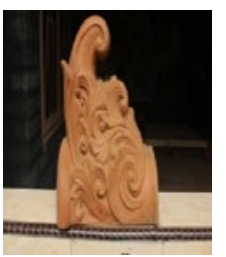

Wuwungan Tiles

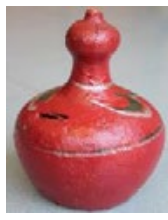

Celengan

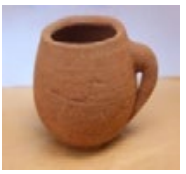

Remitan

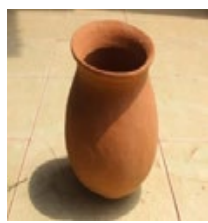

Kendil

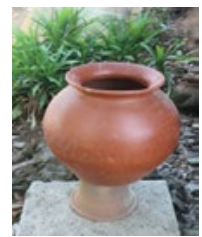

Gentong

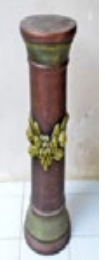

Pot Base

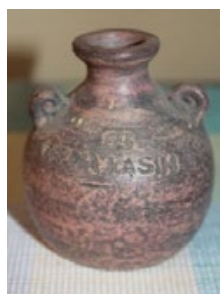

Souvenir

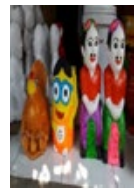

Celengan

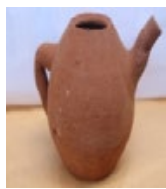

Remitan

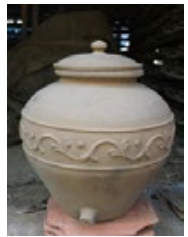

Padasan

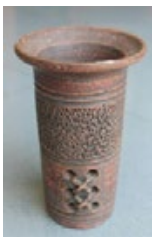

Guci

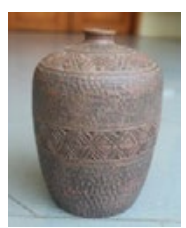

Jarwo

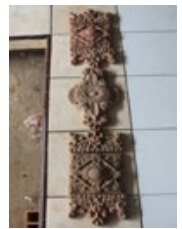

Carving

Fig. 3 The Embodiments and Types of Ceramics produced in Mayong Lor (Source: Author Documentation)

Village, the ceramic pottery in this village has existed since the 15th century.

In subsequent developments, as a social community, Mayong Lor Villagers are a group of people who have a distinctive style in their social and religious life. The pat- terns of interaction and the daily lifestyles of the villagers can be identified as an indicator of the social life. They traditionally develop together to behave in an effort to meet the needs of their life as hardworking, diligent, tenacious, and patient people. 
Ethnically, the local villagers of Mayong Lor are Javanese. As an area located in the northern coastal area of Java (Pantu$\mathrm{ra}$ ), they can be classified as ethnic Javanese Pesisiran (coastal). In the social life of the community, the gotong royong (mutual assistance) still characterizes the lives of the artisans in the village of Mayong Lor. This gotong royong can be seen in some of their social activities and interactions. The gotong royong lifestyle is also performed by the craftsmen in some activities, for example in the purchase of clay raw materials, clay processing and burning.

Beyond the production and distribution process, there are social activities developed traditionally as a means of tying social interaction. In general, the daily social life activities of Mayong Lor villagers are characterized by their interaction in ceramic handicraft production activities with all the supporting processes, starting from communication relationships in family life, neighborhood, arisan (gathering), until solving the problems related to the pottery business. Life goes on a regular basis, flowing from day to day, month to month, year to year into a traditional lifestyle.

Mayong Lor Society's daily behavior prioritizes the simplicity and togetherness in upholding local and religious values. The pattern has made the ceramic work produced by them to be simple and modest in its decoration. This is reinforced by the quality of cultivation which is still "rough". Their principle of life is always to be sincere and nrimo (to accept) no matter how much income they will derive as part of a gift from Allah. They also have the principle to preserve their ancestral heritage so they tend to work their ceramic form that is not out of the grip from ancestral traditions. The aesthetic expressions of ceramics which they have created become one correlation and one unity with the soul and expression of the craftsmen.

One or two artisans do make ceramics with elaborate and artistic shapes and cultivating qualities that may be fine, but they are still limited and casuistic. Some craftsmen who produce ceramics in their unique and artistic shapes are a phenomenon that indicates the need to develop their creativity in order to preserve the existence and sustainability of the business.

The craftsmen struggle in their creative process to find and discover new forms that are in addition to its artistic value as well as, and this is more important, economic value. The goal is clear, that is to preserve the business that became its main livelihood. It is through this action that they see and study market demands to develop their ideas in an effort to create creative and innovative forms.

\section{Aesthetic Adaptation Patterns}

In the context of following the trend of the market, there are indeed some craftsmen who adapt the aesthetic forms such as children toys made in the plastics industry and animated cartoons aired on television. The aesthetic adaptation here is interpreted as a cultural mechanism, a process of using knowledge, values, and beliefs in an effort to cope with environmental changes by utilizing the resources it has to develop the design of a work of art that is capable of aesthetically suiting the evolving needs of the market. The development refers to a fundamental change of the old things that are processed into a new form which means that an attempt repairs in an effort to improve the quality (Rohidi 2001; Hamilton 2009; Gustami 2014). Indeed, at first, the renewal could be considered as something strange to traditional craftsmen. However, after the results of the renewal shows a positive result, the renewal will be followed by other craftsmen.

The renewal adaptation techniques and aesthetic forms of the old piggy banks into newer piggy banks based on the cartoon characters from the internet or television have begun to spread to other craftsmen who become a kind of followers. The goal is to ensure that the production of ceramics with this new design will able to reach the public demands and to overcome the fierce competition in the market.

The existence of some craftsmen who produce ceramics in their unique and artis- 
tic forms is a symptom that indicates the need to develop their creativity in order to maintain the existence and sustainability. They struggle in their creative process to search for and find new designs which helps them to add artistic values and economical values for their products.

The below table 1 is a matrix that presents an overview of differences in the design of the traditional and new designs which embody the aesthetic adaptation. In the matrix of the craftsmen, their efforts to develop a more innovative designs patterns as a form of creative response in reading the market opportunity is seen. The creative responses appear mainly on how they adapt the aesthetic values of simple shapes to form a more unique appearance and lively contrasting coloring designs.

The old ceramic has difficult selling values even though the marketing area is sufficiently expanded. The situation makes the craftsmen adapt as a way to survive by making ceramic design to be more focused on the adjustment of the popular ceramic design and to make it more beautiful and attractive. The consideration of the craftsmen is in accordance with the statement of Hamilton (2009) which states that the main criterion of someone to buy a product lies in the model form of pottery. Aesthetic adaptation process aims to produce more beautiful ceramic in accordance with the changing demands of the market tastes. Therefore,

Table 1. The Difference Matrix between the Old and New Ceramics Design of Mayong Lor Village as Embodiment of Aesthetic Adaptation

The Old Ceramic Design

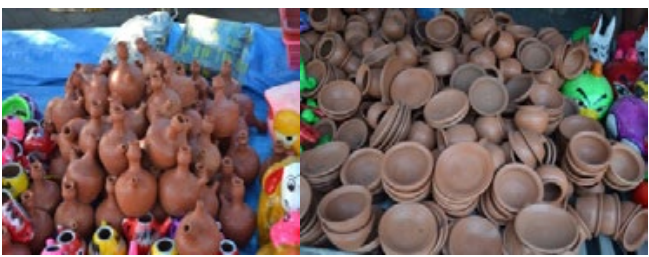

- The ceramic design focuses more specifically on meeting the domestic appliances, kitchen appliances and children's toys that have a grip shape.

- The ceramic Design is more inspired than existing forms because they still lack a source of inspiration for developing more valuable ceramic art.

- The form designs are less able to follow the market appetite so they are less varied.

- The designs have not yet adjusted to the symbolization or icons that are present and updated.

- The colors which are used are more into brown plain. Some of products are colorful such as children toys.

- There is no creative innovation. The design is functioned as a functional object .
The New Ceramic Design as Embodiment of Aesthetic Adaptation

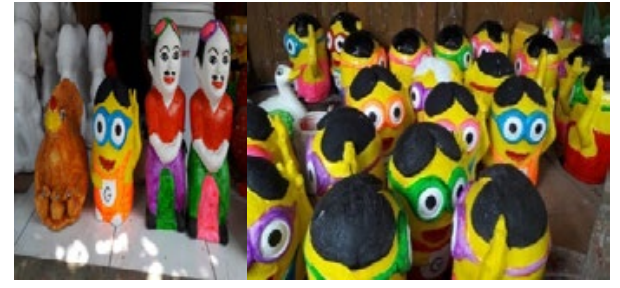

The ceramic design, while still producing household appliances, also begins to focus on a piggy bank with its innovative and creative designs adjusted to the dynamics of the time.

The ceramic designs focus on working on the children toys which mostly are inspired by plastic and animated cartoons aired on television.

- The ceramic design is sought to adjust and to follow the trend of the market, mainly the figures of children such as the cartoon figures of Adit, Sopo, Jarwo, Minion, Spiderman, SpongeBob, etc.

- The design begins to use the symbol of contemporary trend which prioritizes economic value.

- The colors which are used are more to be varied, bright, strong and light.

- The innovation forms, in addition to functional ceramics, also greatly chases the decoration or entertainment value so that the designs are more memorable, funny, humor and entertaining. 
the emergence of the aesthetic adaptation of ceramic performed by the Mayong Lor craftsmen is because the market demands ceramic design with a more modern style and the desire of craftsmen to earn better income.

The craftsmen with market foresight will choose the most popular icons potential to be favored by the market, especially the children. The strategy is later actualized in the form of a new design of piggy bank. The conventional piggy bank icon is replaced with a new one with still maintaining the functional aspect as a place to save money. The techniques of manufacture and marketing models still use conventional models of the old piggy bank design.

Two types of old and new forms of design in fact have their own respective customers. Even recently, the market demands for new ceramic design and it has gained a positive response from consumers. These conditions make craftsmen to be more passionate in their efforts to pursue and maintain their products. The orders keep on flowing. This situation, at least, proves that the aesthetic adaptation performed by the craftsmen have managed to cope with market competition similar to the flood of modern products made of plastic.

\section{CONCLUSION}

The first conclusion is that the type of products that are produced can be classified into four categories, namely: (1) celengan (piggy banks), (2) childrenss toys/remitance (keg, jars, cups, glasses, plates, paso, teapots, earrings, angklo, kekep) , (3) glassware for household purposes, such as jugs, kendil, padasan, and cowek, (4) decorative items (vases, jars, pots, wuwungan tiles, pencil pot, souvenirs, and carving. From four of these categories, there are types which have variant of development and some do not. Aesthetically, the expression on ceramic pottery of Mayong Lor Village is simple and non-complicated. The production prioritizes the aspect of physical function which is oriented to economic value.

Secondly, the environment of Mayong
Lor society both socially and culturally is a community that has typical lifestyle and interaction patterns in an effort to make ends meet. Therefore, the creation of ceramic pottery is conducted through the hereditary process that can ultimately preserve the ceramic industry and continue with the aesthetic and character designs of simple, modest and functional products.

Thirdly, the existence of some craftsmen who produce ceramics in their unique and artistic form is a symptom that indicates the need to develop their creativity by always adapting to the changing times in order to maintain the existence and sustainability. They struggle with the creative process through aesthetic adaptation process to search for and find new forms to add the artistic and economic values for their products. Through this strategy, the existence of Mayong Lor ceramic pottery lasts until now and thrives without leaving a characteristic locality.

Theoretically, the findings of the research shows that the human as a living being basically will always adapt to the challenges and/or changes in the surrounding environment in order to survive in accordance with the knowledge, values, beliefs, technical skills and creativity respectively. This is reflected by the craftsmen of ceramic pottery in Mayong Lor Village who are adapting their product to the popular designs in the form of a piggy bank that is used to be modest and plain. The aesthetic adaptation of craftsmen has not reached the form of ceramics that is more towards pure art or higher artistic value due to the orientation of their work which is focused on the effort to follow the market taste at the bottom layer. It is precisely through this culture of their strategy that until now, they are still viable in developing their business.

\section{REFERENCES}

Adhytman, S., 1987. Kendi: Wadah Air Minum Tradisional. P.T. Yogyakarta, Jakarta.

Adimihardja, et al. 1986. "Keramik: Kerajinan Rakyat Plered di Desa Anjun Kecamatan Plered Kabupaten Purwakarta”. Laporan Penelitian. Bandung: Bagian Proyek Penelitian dan Pengkajian 
Kebudayaan Sunda (Sundanologi) Direktorat Jendral Kebudayaan.

Armitage, D., Berkes, F., Dale, A., Kocho-Schellenberg, E., \& Patton, E., 2011. Co-management and the co-production of knowledge: learning to adapt in Canada's Arctic. Global Environmental Change, 21(3), pp.995-1004.

Astuti, A., 1994. Ilmu Pengetahuan Keramik. Gajah Mada University Press, Yogyakarta.

Babcoc, B.A., 1989. "At Home, Now Womens Are Storyteller : Ceramic Creativity and and the Politics of Discource in Cohiti Pueblo", in: Lavie, S.(eds.). Creativity/Anthropology. Cornell University Press, Ithaca and London.

Bennet, J.W., 1976. The Ecological Transition : Cultural Anthropologiy and Human Adaptation. Pergamon Press Toronto, New York.

Bourdieu, P., 1986. The Forms of Capital".in: J.Richardson (ed). Handbook of Theory and Research for the Sociology of Education. Greenwood, New York.

Carbon, C.C., 2010. The cycle of preference: Longterm dynamics of aesthetic appreciation. Acta psychologica, 134(2), pp.233-244.

Carbon, C.C., 2011. Cognitive mechanisms for explaining dynamics of aesthetic appreciation. $i-P e r-$ ception, 2(7), pp.708-719.

Chambers, R., 1988. Pembangunan Desa Mulai dari Belakang. $\mathrm{LP}_{3} \mathrm{ES}$, Jakarta.

Chamim, A.I, et al. 2003. Purifikasidan Reproduksi Budaya di Pantai Utara Jawa. Kartasura Surakarta: Pusat Studi Budaya dan Perubahan Sosial Universitas Muhammadiyah Surakarta.

Dillistone, F.W., 2002. The Power of Symbols. Terjemahan: A. Widyamartaya. Kanisius, Yogyakarta.

Ellen, R., 1982. Environment, Subsistence, and System: The Ecological of Small-Scale Social Formation. Cambridge University Press, London.

Faerber, S.J., \& Carbon, C.C., 2012. The power of liking: Highly sensitive aesthetic processing for guiding us through the world. i-Perception, $3(8)$, pp. 553-561.

Fonte, M., 2008. Knowledge, food and place. A way of producing, a way of knowing. Sociologia ruralis, 48(3), pp.200-222.

Geertz, C., 1973. The Interpretation of Culture: Selected Essays. Basic Books, New York.

Gopnik, H., 2oo. The Ceramic of Godin II : Ceramic Variabilty in the Archeological Record, Ph.D Dissertation, Departement of Near an Midle Eastern Civilizations, Univesity Toronto, Canada.

Guntur. 2005. Keramik Kasongan. Bina Citra Pustaka, Wonogiri.

Gustami, et al. 2014. Craft Arts and Tourism in Ceramic Art Village of Kasongan in Yogyakarta. Journal of Arts and Humanities, 3(2).

Hamilton, A., 2009 Scruton's Philosophy of Culture: Elitism, Populism, and Classic Art. British Journal of Aesthetics, 49(4), pp.389-404. https://doi.org/10.1093/aesthj/aypo35.

Iswidayati, S., et al. 2009. Seni Keramik Nusantara :
Dilematis antara Upaya Pelestarian dan Tuntutan Pasar. Laporan Hasil Penelitian. LP2M Unnes.

Karthadinata, D.M., 2005. Studi tentang Pengembangan Desain Kerajinan Keramik Desa Mayong Lor. Imajinasi, Jurnal Seni, 1(2).

Kayam, U., 1981. Seni, Tradisi, Masyarakat. Sinar Harapan, Jakarta.

Kisawa, W., 2012. Kesenian Rakyat Sungguh Dahsyat, dalam: Suara Merdeka, Minggu 14 Oktober 2012, hal.7.

Koentjaraningrat (ed.), 1984. Masalah-masalah Pembangunan, Bunga Rampai Antropologi Terapan. $\mathrm{LP}_{3} \mathrm{ES}$, Jakarta.

Mahbub, J., 2010. Perkembangan Industri Kerajinan Keramik dan Peranannya terhadap Kehidupan Sosial Ekonomi Masyarakat Desa Mayong Lor Jepara Tahun 1980-2005. Skripsi Ilmu Sejarah dalam eprints.undip.ac.id/3421.

Maina, C.K., 2012. Traditional knowledge management and preservation: Intersections with library and information science. The International Information E Library Review, 44(1), pp.13-27.

Mayong.jeparakab.go.id/index.php/web/data/6.8.

Miles, M.B. dan Hubermen, A.M., 1992.Analisis Data Kualitatif. Terjemahan: T.R. Rohidi. U.I. Press, Jakarta.

Moran, E.F. 1979. Human Adaptability: And Introduction to Ecological Anthropology. Wadworth Publishing Company, Inc., California.

Morton, D., 2010. Sketching Under the Influence? Winsor McCay and the Question of Aesthetic Convergence Between Comic Strips and Film. Animation, 5(3), pp.295-312.

Msuya, J., 2007. Challenges and opportunities in the protection and preservation of indigenous knowledge in Africa. International Review of Information Ethics, 7(9), pp.1-8.

Otten, C.M., 1971. Anthropology and Art: Reading in Cross-Cultural Aethetics. Garden City, New York.

Raymond, C.M., Fazey, I., Reed, M.S., Stringer, L.C., Robinson, G.M., \& Evely, A.C., 2010. Integrating local and scientific knowledge for environmental management. Journal of environmental management, 91(8), pp.1766-1777.

Rogers, E.M. and Shoemaker, W.F., 1971. Communication of Innovations. The Free Press, New York.

Roh, Y.H., Yang, B.K., Noh, J.H., Baek, G.H., Song, C.H., \& Gong, H.S., 2011. Cross-cultural adaptation and validation of the Korean version of the Michigan hand questionnaire. The Journal of hand surgery, 36(9), pp.1497-1503.

Rohidi, T.R., 2001. Kesenian di Indonesia: Keragaman dan Perubahannya. Makalah Seminar Nasional Universitas Negeri Makasar 28 Pebruari 2010

Rohidi, T.R., 2011. Metodologi Penelitian Seni. Cipta Prima Nusantara, Semarang.

Runco, M.A., 2007. Creativity, Theories and Themes: Research, Development, and Practice. Aca- 
demic Press, New York.

Sachari, A., 1989.Estetika Terapan, Spirit-spirit Yang Menikam. Nova, Bandung.

Sayogyo, P., 1985. Peranan Wanita dalam Perkembangan Masyarakat Desa. C.V. Rajawali, Jakarta.

Sedyawati, E., 1991. "Pelestarian dan Pengembangan Kesenian Tradisi Indonesia”.Makalah dalam Konggres Kebudayaan 1991 di Jakarta.

Sidharta, H., 1991. Seni Keramik Modern dalam Perjalanan Seni Rupa Indonesia. Penerbit Panitia KIAS, Bandung.

Spradley, J.P., 1997. Metode Etnografi. Terjemahan Misbah Zulfa E. PT. Tiara Wacana Yogya, Yogyakarta.

Suara Merdeka. Edisi Minggu, 9 Maret 2014, halaman
12.

Sudiyati, N., 2012. Keramik Singkawang Kalimantan Barat: Kajian Aspek Estetika. Disertasi Program Doktor Bidang Pengkajian Seni UGM Yogyakarta.

Sugiharto, I.B., 2013. Untuk Apa Seni. Matahari, Bandung.

Weber, E.P., \& Khademian, A.M., 2008. Wicked problems, knowledge challenges, and collaborative capacity builders in network settings. Public administration review, 68(2), pp.334-349.

Wolff, J., 1989. The Social Production of Art. New York University Press, New York.

Yumarta, K., 1982. Keramik. Angkasa, Bandung. 